\title{
BIOLOGICAL ASPECTS AND PREDATORY CAPACITY OF Podisus nigrispinus (Dallas) (Hemiptera: Pentatomidae) FED ON Alabama argillacea (Hübner) (Lepidoptera: Noctuidae) REARED ON COTTON GENOTYPES
}

\author{
Terezinha Monteiro dos Santos; Arlindo Leal Boiça Jr.* \\ Depto. de Fitossanidade - UNESP/FCAV, Via de Acesso Prof. Paulo Donato Castellane, s/n - CEP: 14884-900 - \\ Jaboticabal, SP, Brazil. \\ ${ }^{*}$ Corresponding author <aboicajr@fcav.unesp.br>
}

\begin{abstract}
Host plants may influence indirectly biological characteristics of predators, on a positive or negative way, poiting out the importance of studies evaluating the effect of cultivars on the third trophic level. This study evaluates the biological aspects and predatory capacity of Podisus nigrispinus adults fed Alabama argillacea larvae reared on cotton genotypes. The predator was fed daily with fourth instar larvae reared on leaves of the following genotypes CNPA Precoce 1 (hirsute), CNPA 9211-31 (high gossypol level), CNPA 9211-41 (medium gossypol level) and GL2 GL3 (gossypol glandless). The pre-oviposition, oviposition and post-oviposition periods and the oviposition capacity of $P$. nigripinus were not affected when preyed on cotton leafworms reared on the listed cotton genotypes. Mean weight of predator females was higher (126.2 mg) when they fed on A. argillacea reared on GL2 GL3 cotton leaves, in comparison to the observed weight (96.2mg) of $P$. nigripinus females fed on larvae reared on CNPA 9211-41. Longevity of $P$. nigrispinus ranged 30.7 to 31.5 days for females and 38.0 to 66.3 days for males. P. nigrispinus females preyed 125.2 to $184.0 \mathrm{~A}$. argillacea larvae during its adult stage, while adult males preyed 135.7 to 205.0 leafworms. Using plant resistance in association with $P$. nigrispinus is viable to control $A$. argillacea, because resistant genotypes do not influence negatively the biological characteristics of the predator.
\end{abstract}

Key words: cotton leafworm, predator, biological control, plant resistance

\section{ASPECTOS BIOLÓgICOS E CAPACIDADE PREDATÓRIA DE Podisus nigrispinus (Dallas) (Hemiptera: Pentatomidae) ALIMENTADO COM Alabama argillacea (Hübner) (Lepidoptera: Noctuidae) CRIADA EM GENÓTIPOS DE ALGODOEIRO}

\begin{abstract}
RESUMO: Plantas hospedeiras podem influenciar indiretamente as características biológicas do predador, de maneira positiva ou negativa, ressaltando assim a importância de estudos relacionando o efeito de cultivares sobre o terceiro nível trófico. Este trabalho avalia os aspectos biológicos e a capacidade predatória de adultos de Podisus nigrispinus alimentados com lagartas de Alabama argillacea criadas em genótipos de algodoeiro. Diariamente o predador foi alimentado com lagartas de quarto ínstar criadas com folhas de algodoeiro CNPA Precoce 1 (média pilosidade), CNPA 9211-31 (alto teor de gossipol), CNPA 9211-41 (teor médio de gossipol) e GL2 GL3 (sem gossipol). Essas plantas oferecidas como alimento às lagartas não influenciaram os períodos de pré-oviposição, oviposição e pós-oviposição e a capacidade de oviposição do predador. O peso médio das fêmeas foi maior $(126,2 \mathrm{mg}$ ) quando elas foram alimentadas com lagartas de $A$. argillacea criadas em folhas do genótipo GL2 GL3, em comparação com aquele $(96,2 \mathrm{mg})$ de fêmeas que se alimentaram de lagartas criadas em folhas do genótipo CNPA 9211-41. A longevidade de fêmeas do predador variou de 30,7 a 31,5 dias, enquanto que a dos machos apresentou intervalo de variação de 38,0 a 66,3 dias. Fêmeas de $P$. nigrispinus predaram, em média, de 125,2 a 184,0 lagartas, durante a fase adulta, enquanto os machos predaram no mínimo 135,7 e no máximo 205,0 lagartas. Para o controle de A. argillacea, a utilização de plantas resistentes em associação com $P$. nigrispinus é viável, pois genótipos resistentes não influenciam negativamente as características biológicas do predador.

Palavras-chave: curuquerê-do-algodeiro, predador, controle biológico, resistência de plantas
\end{abstract}

\section{INTRODUCTION}

The cotton leafworm Alabama argillacea (Hübner, 1818) is one of the main pests of this crop in Brazil (Soares et. al., 1995). The larvae are defoliaters which, depending on the density, can reduce production rather significantly (Gravena \& Cunha, 1991). The control of the pest in the cotton crop is ordinarily done by chemicals
(Lutrell, 1994). The exclusive application of these products has contributed to the outbreaks of pests and the resistance of insect pests to several insecticides (Soares et al., 1995), being of great importance, alternative control methods (Oliveira et al., 2000), like plant resistance and biological control, two of the most used technologies for integrated pest management (Pimentel, 1991). 
In cotton ecosystems, hundreds of thousands of arthropods are found, mainly predators and parasites of phytophagous species (Lutrell et al., 1994). The predators of the genera Podisus are polyphagous, with great potential for the control of bugs and moths (Zanuncio et al., 1994; De Clercq et al., 1998). The cotton leafworm is considered a natural prey of Podius sp. in cotton crops all through the State of São Paulo (Gravena \& Lara, 1982), being an adequate prey for the nymphal development of Podius nigrispinus (Santos et al., 1995).

The association between plant resistance and biological control is considered adequate for systems carried under integrated pest management. However, the development of resistant cultivars to insect pests does not always take in account the influence of resistant factors on pests natural enemies (Schuster et al., 1976).

The nutritional substrate of a host plant may influence indirectly the predator, either in a positive or negative way. When a prey feeds on resistant plants, it usually presents reduction on the growth rate, increased duration of the developmental period and mortality rates, and decrease in fecundity (Bergman \& Tingey, 1979). According to these authors, the nutritional quality of this prey is modified, affecting negatively its natural enemy. Rogers \& Sullivan (1986) determined a greater mortality of Geocoris punctipes Say (Lygaeidae) when this predator was fed Anticarsia gemmatalis Hübner (Noctuidae) larvae reared in soybean leaves genotypically resistant to this lepidopter. Orr \& Boethel (1986), studying the effects of antibiosis on four trophic levels, observed that this resistance mechanism may influence the biology of the pest and of its natural enemy. Rodrigues et al. (1997), studying the importance of nectaries of cotton plant leaves on the populations of $A$. argillacea and its natural enemy, $P$. nigrispinus, observed that the longevity and the number of eggs of the predator were smaller for the CNPA Precoce 2 cultivar (without nectaries). De Clerq et al. (2000), evaluating the effect of the host plant over the functional response of $P$. nigrispinus in relation to the prey Spodoptera exigua (Hübner, 1801) (Noctuidae), observed that the glandular trichomes and the allelochemicals of the tomato plant interfered in the success rate of the predator, impairing search efficiency and preying capacity.

On the other hand, many researchers have demonstrated that plant resistance can be positively associated to the action of the natural enemy (Farid et al., 1997). Cotton genotypes that have high gossypol contents acted negatively over the pest $A$. argillacea, affecting its development and, consequently, increasing the effectiveness of $P$. nigrispinus predacious nymphs, because of the lower size of the prey (Santos, 2001).

Considering the importance of the relationship between resistant cultivars, phytophagous insects and their natural enemies, this research aimed to study the indirect effect of $A$. argillacea larvae reared on leaves of cotton genotypes on biological aspects and the predatory capacity of $P$. nigrispinus.

\section{MATERIAL AND METHODS}

The study was carried out in Jaboticabal, SP, Brazil, inside climatic chambers $\left(25 \pm 1^{\circ} \mathrm{C}, 70 \pm 10 \% \mathrm{RU}\right.$; 12 hour photophase). Predator specimens, P. nigrispinus were maintained in the laboratory and fed Tenebrio molitor L. (Coleoptera: Tenebrionidae) and Musca domestica L. (Diptera: Muscidae) larvae. For the mass rearing of $A$. argillacea, the larvae were reared on cotton plant leaves of the cultivar IAC 22 and the adults fed on a 1:1 honey-water solution.

The trials were set up in a completely randomized design, with 20 replications. Treatments consisted of $A$. argillacea leafworms reared on leaves of CNPA Precoce 1, CNPA 9211-31, CNPA 9211-41 and GL2 GL3 cotton genotypes. Young adult males and females of $P$. nigrispinus were sexed (Zanuncio, 1992), paired and maintained in plastic white jars, $4.5 \mathrm{~cm}$ height and 7.5 $\mathrm{cm}$ of diameter. Six forth-instar A. argillacea caterpillars, fed cotton plant leaves of genotypes CNPA 9211-31 (high gossypol level), CNPA 9211-41 (medium gossypol level), CNPA Precoce 1 (hirsute) and GL2 GL3 (gossypol glandless), were offered as prey daily. To maintain the humidity and water supply to the predators, a $2.5-\mathrm{mL}$ glass tube (anesthetic type) containing water, with the open end sealed with a cotton padding and facing the inside of the jars, was introduced through a $1-\mathrm{cm}$ opening made on the lid of each jar. The following variables were evaluated: pre-oviposition, oviposition and post-oviposition periods; number of eggs per female; body weight at 30 days and longevity of males and females.

For the evaluation of the predatory capacity, adult $P$. nigrispinus were separated in plastic jars, $4.5 \mathrm{~cm}$ high, having $7.5 \mathrm{~cm}$ in diameter. Seven forth-instar $A$. argillacea leafworms, fed on cotton plant leaves of the four genotypes were added to each jar. The leafworms were removed daily, and considered as preyed those that presented lesions on the tegument, lack of mobility and body content totaly or partially sucked by the predator. The number of $A$. argillacea leafworms preyed daily by $P$. nigrispinus during the adult phase was determined.

Experimental data were analysed by ANOVA and treatment means were compared through the Tukey test $(P<0.05)$. The statistical package STAT, version 2.0, was used for the statistical analysis (UNESP, 1994).

\section{RESULTS AND DISCUSSION}

\section{Biological aspects of P.nigrispinus}

The cotton genotypes CNPA Precoce 1, GL2 GL3, CNPA 9211-41 and CNPA 9211-31 offered as food to $A$. argillacea leafworms did not influence the periods of pre-oviposition, oviposition e post-oviposition of the predator (Table 1).

The pre-oviposition period of $P$. nigrispinus varied from 4.2 to 4.8 days; these values were inferior 
to those obtained by Medeiros et al. (1999) and Oliveira (2000) who observed periods of 8.3 to 5.8 days, respectively, for females of this same species when fed A. argillacea leafworms reared on cotton plant leaves of the genotype CNPA Precoce 1. The oviposition period varied from 25.0 to 42.8 days (Table 1). Oliveira (2000) registered for females of $P$. nigrispinus a minimum period of 4.0 and a maximum of 46.0 days. Females of $P$. nigrispinus fed $A$. argillacea leafworms reared on leaves of CNPA 9211-41, CNPA Precoce 1, CNPA 9211-31 and GL2 GL3 genotypes presented postoviposition periods of $2.0 ; 4.0 ; 5.1$ and 7.7 days, respectively (Table 1 ).

There was no difference $(P>0.05)$ between the total number of eggs laid by females of $P$. nigrispinus (Figure 1). The average number of eggs varied from 296.3 to 611.7 , when the predator females were fed, respectively, $A$. argillacea leafworms reared on leaves of GL2 GL3 and CNPA Precoce 1 genotypes. Medeiros et al. (1999) and Oliveira (2000) observed lower values, respectively, 188.5 and 303.5 eggs per females of $P$. nigrispinus fed $A$. argillacea leafworms reared on leaves of CNPA Precoce 1 genotype.

The genotype CNPA 9211-31 presents antibiosis resistance to $A$. argillacea (Ferreira \& Lara, 1999) and the genotype CNPA 9211-41 plant is not considered appropriate for its development (Santos, 2001). In the present study, these materials did not indirectly influence in the reproductive capacity of $P$. nigrispinus. Such results are important, because the gossypol antibiotic effect present in the cotton genotypes did not pass from the phytophagous to the predator, when fed $A$. argillacea leafworms. On the other hand, even though Orr \& Boethel (1986) did not find alteration in the fecundity of $P$. maculiventris fed caterpillars reared in resistant host plants, these authors observed that the egg production period of the female was smaller, reducing the intrinsic increase rate of the predator.

Table 1 - Pre-oviposition, oviposition and post-oviposition periods of $P$. nigrispinus fed $A$. argillacea leafworm reared on leaves of different cotton genotypes at $25 \pm 1^{\circ} \mathrm{C}, \mathrm{RU} 70 \pm 10 \%$, and 12 hour photophase.

\begin{tabular}{lccc}
\hline \multirow{2}{*}{ Genotype } & \multicolumn{3}{c}{ Period (days) $^{1}$} \\
\cline { 2 - 4 } & Pre-oviposition & Oviposition & Post-oviposition \\
\hline CNPA & $4.3 \pm 0.3 \mathrm{a}$ & $32.3 \pm 5.1 \mathrm{a}$ & $4.0 \pm 1.4 \mathrm{a}$ \\
Precoce1 & $4.7 \pm 0.3 \mathrm{a}$ & $23.7 \pm 9.8 \mathrm{a}$ & $7.7 \pm 0.9 \mathrm{a}$ \\
GL2 GL3 & $4.8 \pm 0.5 \mathrm{a}$ & $25.0 \pm 8.4 \mathrm{a}$ & $2.0 \pm 0.3 \mathrm{a}$ \\
CNPA 9211-41 & $4.0 \pm 0.5 \mathrm{a}$ & $42.8 \pm 10.5 \mathrm{a}$ & $5.1 \pm 2.5 \mathrm{a}$ \\
CNPA 9211-31 & $4.2 \pm 0.0^{\mathrm{ns}}$ & $1.0^{\mathrm{ns}}$ & $2.9^{\text {ns }}$ \\
\hline F (treatment) & $0.5^{\mathrm{n}}$ & 67.4 & 71.5 \\
CV (\%) & 21.7 &
\end{tabular}

${ }^{1}$ Original data; SD = standard deviation

Data followed by the same letter in a column do not differ (Tukey test, $(P=0.05)$.

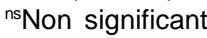

The mean weight of $P$. nigrispinus females (126.2 $\mathrm{mg}$ ) was larger when they were fed $A$. argillacea leafworms reared on genotype GL2 GL3 leaves, in comparison to the weight of females that fed on leafworms reared on leaves of the genotype CNPA 921141 (96.2 mg). This value did, however, not differ from the weight of the females fed on leafworms reared on leaves of the other genotypes (Figure 2).

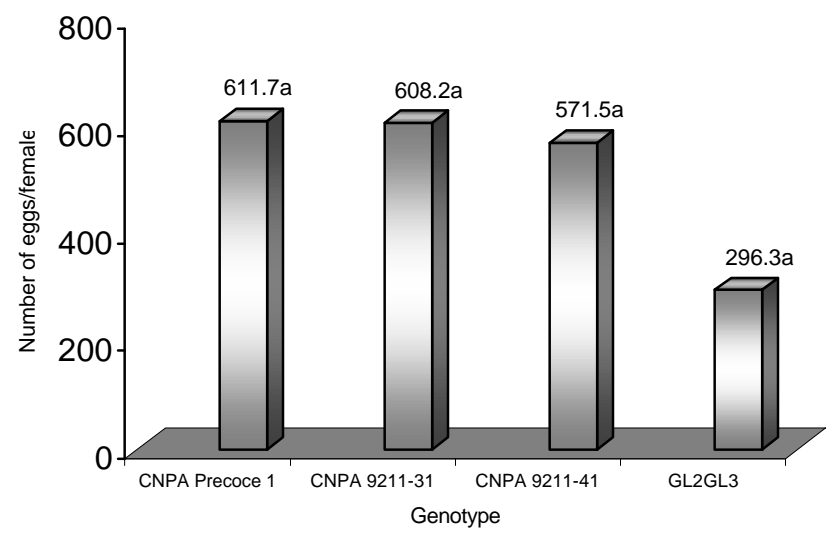

Figure 1 - Mean number of eggs per $P$. nigrispinus female fed $A$ argillacea leafworm reared on leaves of different cotton genotypes at $25 \pm 1^{\circ} \mathrm{C}$, RU $70 \pm 10 \%$, and 12 hour photophase.

Females

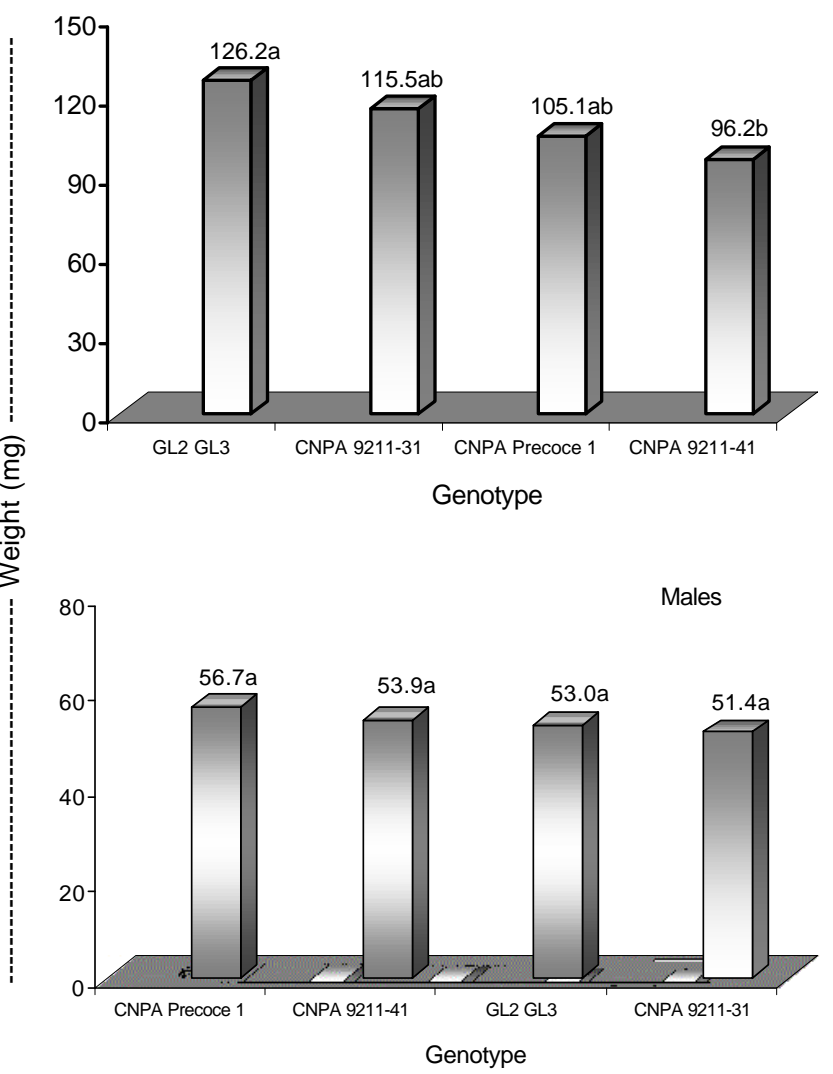

Figure 2 - Mean weight of $P$. nigrispinus 30-day old, fed $A$. argillacea leafworm reared on leaves of different cotton genotypes at $25 \pm 1{ }^{\circ} \mathrm{C}, \mathrm{RU} 70 \pm 10 \%$, and 12 hour photophase. 
Because genotype GL2 GL3 does not contain gossypol, it presents susceptibility to $A$. argillacea, enabling a higher larval weight of this species when fed with leaves of this genotype (Oliveira, 1996). On the other hand, $A$. argillacea leafworms fed on leaves of genotypes CNPA 9211-41 and CNPA 9211-31 present reduced size because these materials present, respectively, medium and high contents of gossypol (Santos, 2001). This substance promotes reduction in the development and larval size of some lepidoptera (Zummo et al. 1983). That explains, in part, why $P$. nigrispinus female fed cotton leafworms reared on genotype GL2 GL3 leaves present higher weight. There was no significant influence of the cotton genotypes over this variable on males, which varied from 51.4 to $56.7 \mathrm{mg}$ in weight (Figure 2).

The prey, cotton leafworm $A$. argillacea reared on leaves of different genotypes, did not influence the mean longevity of $P$.nigrispinus (Table 2). For $P$. nigrispinus males, this parameter varied from 38.0 to 66.3 days, when fed, respectively, on leafworms reared on CNPA 9211-41 and CNPA Precoce 1 genotypes. For the females fed $A$. argillacea reared leafworms, respectively, on leaves of CNPA Precoce 1 and CNPA 9211-31 genotypes, the mean longevity was of 30.7 to 48.6 days. These values were similar to those observed by Medeiros et al. (2000) and Oliveira (2000), who observed that female $P$. nigrispinus fed on cotton leafworm reared on leaves of genotype CNPA Precoce 1, presented mean longevity of 31.2 and 31.5 days, respectively.

\section{Predatory capacity of $P$. nigrispinus}

The daily mean number and total number of $A$. argillacea leafworms preyed during the adult phase of $P$. nigrispinus were not influenced by the genotypes (Figures 3 and 4). P. nigrispinus females preyed on average, daily 2.4 to 3.5 leafworms, and males 2.3 to 2.9 (Figure 3). These values are larger than those observed by Oliveira (2000), who reported that $P$. nigrispinus females and

Table 2 - Longevity of $P$. nigrispinus fed $A$. argillacea leafworm reared on leaves of different cotton genotypes at 25 $\pm 1^{\circ} \mathrm{C}, \mathrm{RU} 70 \pm 10 \%$, and 12 hour photophase.

\begin{tabular}{lcc}
\hline \multirow{2}{*}{ Genotype } & \multicolumn{2}{c}{ Longevity $^{1}$} \\
\cline { 2 - 3 } & Female & male \\
\hline & Mean \pm SD & Mean \pm SD \\
CNPA Precoce1 & $30.7 \pm 4.2 \mathrm{a}$ & $66.3 \pm 7.8 \mathrm{a}$ \\
GL2 GL3 & $36.0 \pm 9.9 \mathrm{a}$ & $55.0 \pm 10.8 \mathrm{a}$ \\
CNPA 9211-41 & $42.5 \pm 11.5 \mathrm{a}$ & $38.0 \pm 7.2 \mathrm{a}$ \\
CNPA 9211-31 & $48.6 \pm 10.1 \mathrm{a}$ & $50.6 \pm 7.7 \mathrm{a}$ \\
\hline F (treatment) & $0.8^{\text {ns }}$ & $1.8^{\text {ns }}$ \\
CV (\%) & 52.8 & 38.4 \\
\hline
\end{tabular}

${ }^{1}$ Original data; SD $=$ standard deviation

Data followed by the same letter in a column do not differ (Tukey test, $P=0.05$ )

${ }^{\text {ns Non significant }}$

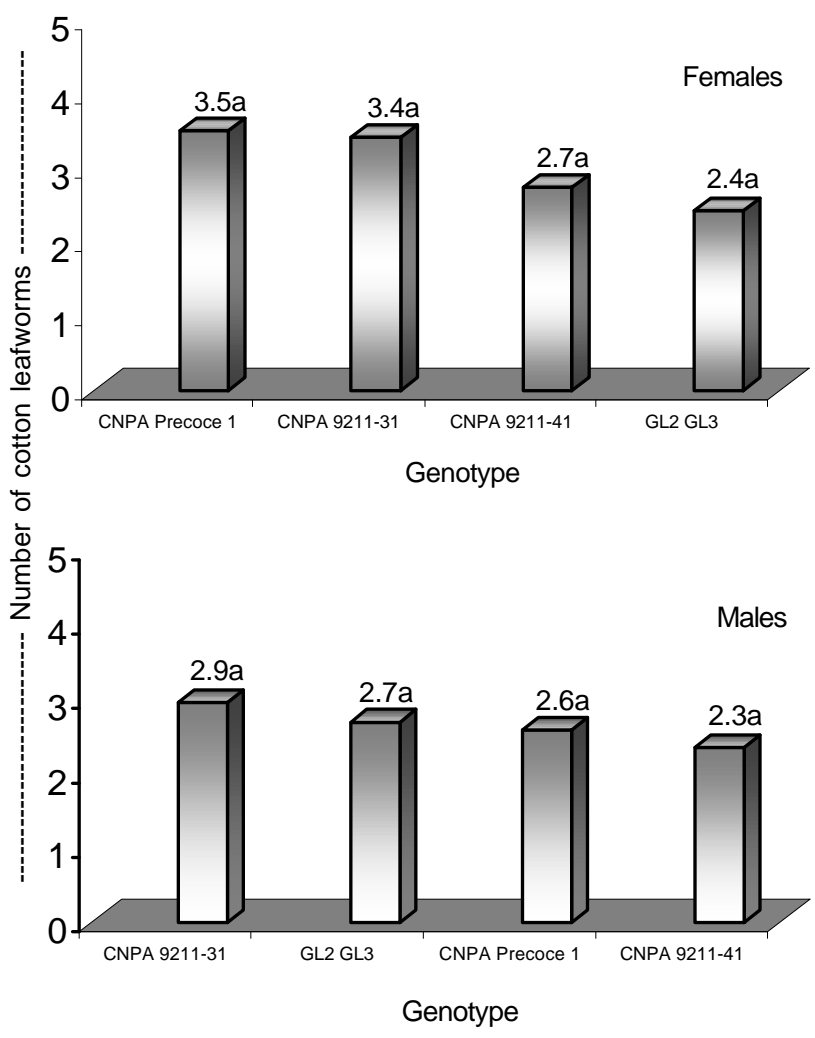

Figure 3 - Mean number of $A$. argillacea leafworm preyed daily by $P$. nigrispinus at $25 \pm 1{ }^{\circ} \mathrm{C}, \mathrm{RU} 70 \pm 10 \%$, and 12 hour photophase.

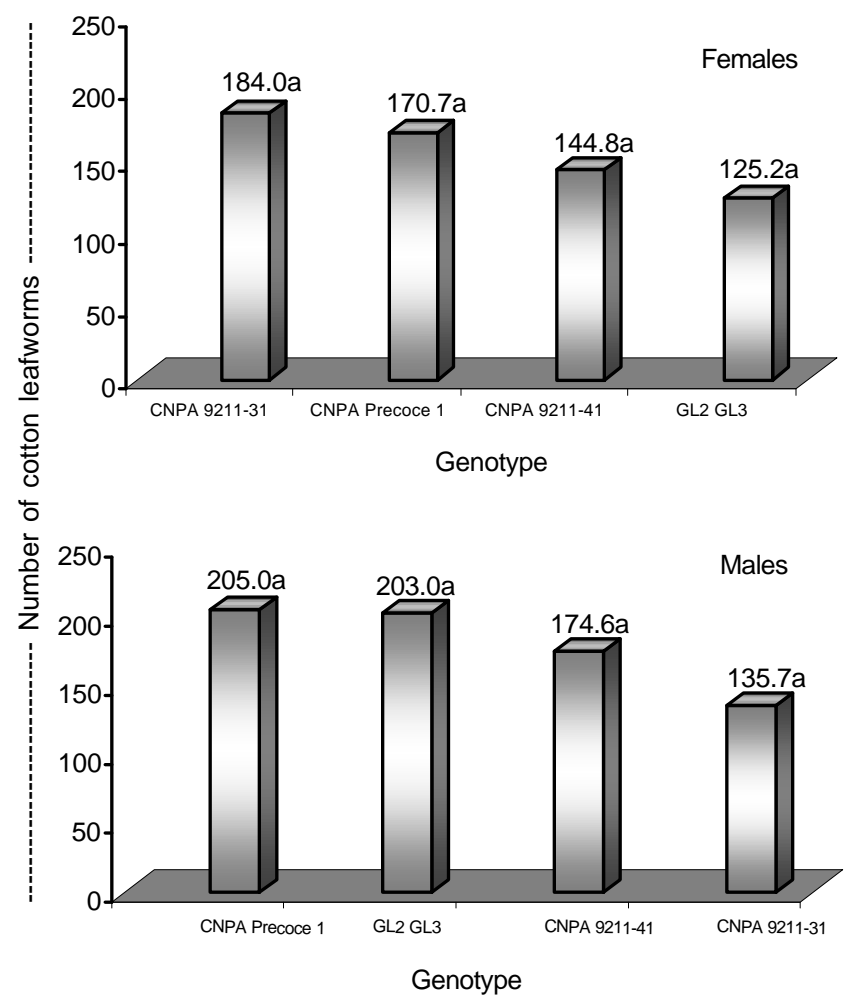

Figure 4 - Total mean number of $A$. argillacea leafworm preyed daily by $P$. nigrispinus at $25 \pm 1{ }^{\circ} \mathrm{C}, \mathrm{RU} 70 \pm 10 \%$, and 12 hour photophase. 
males can prey mean, respectively, means of 1.4 and 1.7 A. argillacea larvae of third instar, daily, under field conditions. The number of $A$. argillacea leafworms preyed during the adult phase of $P$. nigrispinus females varied from 125.2 to 184.0 . In relation to males, the minimum number of leafworms was 135.7 and the maximum 205.0 (Figure 4).

Because resistant plant genotypes do not interfere negatively on the biological characteristics of this predator, the utilization of resistant plant genotypes in association to $P$. nigrispinus is viable. However, future field studies, evaluating the association between resistant plants and biological control of the cotton leafworm are needed. These two strategies can be associated for an integrated pest control of this lepidopterous on cotton crops.

\section{ACKNOWLEDGEMENTS}

To FAPESP for the financial support of this study.

\section{REFERENCES}

BERGMAN, J.M.; TINGEY, W.M. Aspects of interactions between plant genotypes and biological control . Bulletin of Entomological Society of America, v.25, p.275-279, 1979.

DE CLERCQ, P.; MOGAGHEGH, J.; TIRRY, L. Effect of host plant on the functional response of the predator Podisus nigrispinus (Heteroptera: Pentatomidae). Biological Control, v.18, p.65-70, 2000.

DE CLERCQ, P.; MERLEVED. F.; MESTDAGH, I.; VANDENDURPEL, K.; MOHAGHEGH, J.; DEGHEELE, D. Predation on tomato looper Chrysodeixis chalcites (Esper) (Lep., Noctuidae) by Podisus maculiventris (Say) and Podisus nigrispinus (Dallas) (Het., Pentatomidae). Journal of Applied Entomology, v.122, p.93-98, 1998.

FARID, A.; JOHNSON, J.B.; QUISENBERRY, S.S. Compatibility of a coccinellid predator with a Russian wheat aphid resistant wheat. Journal of the Kansas Entomological Society, v.70, p.114-119, 1997.

FERREIRA, A.; LARA, F.M. Tipos de resistência a Alabama argillacea (Huebner, 1818) (Lepidoptera: Noctuidae) envovidos em genótipos de algodoeiro: II. Antibiose. Bragantia, v.58, p.287-292, 1999.

GRAVENA, S.; CUNHA, H.F. Artrópodos predadores na cultura algodoeira: atividade sobre Alabama argillacea (Hueb.) com breves referências a Heliothis sp. (Lepidoptera: Noctuidae). Jaboticabal: FUNEP, 1991. 41p. (Boletim Técnico CEMIP).

GRAVENA, S.; LARA, F.M. Controle integrado de pragas e receituário agronômico. In: GRAZIANO NETO, F. (Ed.) Receituário agronômico. São Paulo: Agroedições, 1982. p.123-161.

LUTTRELL, R.G. Cotton pest management: Part 2. A US perspective. Annual Review of Entomology, v.39, p.527-542, 1994.

LUTTRELL, R.G.; FITT, G.P.; RAMALHO, F.S.; SUGONYAEV, E.S. Cotton pest management: Part 1. A Worldwide perspective. Annual Review of Entomology, v.39, p.517-526, 1994.

MEDEIROS, R.S.; RAMALHO, F.S.; LEMOS, W.P.; ZANUNCIO, J.C. Agedependent fecundity and life-fertility tables for Podisus nigrispinus (Dallas) (Het., Pentatomidae). Journal of Applied Entomology, v.124, p.319-324, 2000 .
MEDEIROS, R.S. de; LEMOS, W.P.; RAMALHO, F.S.; PEREIRA, F.P.; ZANUNCIO, J.C. Potencial reprodutivo de Podisus nigrispinus (Dallas) (Heteroptera: Pentatomidae), tendo como presa lagartas do curuquerêdo-algodoeiro. In: CONGRESSO BRASILEIRO DE ALGODÃO, 2., Ribeirão Preto, 1999. Anais. Campina Grande: Embrapa Algodão, 1999. p.285-287.

OLIVEIRA, J.E. de M. Desenvolvimento e reprodução de Podisus nigrispinus (Heteroptera: Pentatomidae) em plantas de algodão e de tomate e seu potencial para o controle de Alabama argillacea (Lepidoptera: Noctuidae). Recife, 2000. 96p. Dissertação (Mestrado) - Universidade Rural de Pernambuco.

OLIVEIRA, R.H. Resistência de algodoeiro (Gossypium sp.) ao curuquerê Alabama argillacea (Hübner, 1818) (Lepidoptera: Noctuidae). Areia, 1996. 65p. Monografia (Graduação) - Universidade Federal da Paraíba.

OLIVEIRA, R.H.; SOARES, J.J.; JÁCOME, A.G. Influência de genótipos de algodoeiro (Gossypium sp.) na biologia de Alabama argillacea. Revista de Oleaginosas e Fibrosas, v.4, p.9-12, 2000.

ORR, D.B.; BOETHEL, D.J. Influence of plant antibiosis through four trophic levels. Oecologia, v.70, p.242-249, 1986.

PIMENTEL, D. Diversification of biological control strategies in agriculture. Crop Protection, v.10, p.243-253, 1991

RODRIGUES, L.F.; OLIVEIRA, R.H. de; MEZZOMO, J.J.; SOARES, J.J. Influência de genótipos de algodoeiro com e sem nectários nas populações de Alabama argillacea (Lepidoptera: Noctuidae) e de seu predador Podisus nigrispinus (Hemiptera: Pentatomidae). In: CONGRESSO BRASILEIRO DE ENTOMOLOGIA, 16., Salvador, 1997, Resumos. Salvador, SEB EMBRAPA, CNPMF, 1997. p.334.

ROGERS, D.J.; SULLIVAN, M.J. Nymphal performance of Geocoris punctipes (Hemiptera: Lygaeidae) on pest-resistant soybeans. Environmenta Entomology, v.15, p.1032-1036, 1986.

SANTOS, T.M. dos Influência de genótipos de algodoeiro sobre Alabama argillacea (Hübner, 1818) (Lep.: Noctuidae) e seu predador Podisus nigrispinus (Dallas, 1851) (Hem.: Pentatomidae). Jaboticabal, 2001. 111p. Tese (Doutorado) - Faculdade de Ciências Agrárias e Veterinárias, Universidade Estadual Paulista "Júlio de Mesquita Filho".

SANTOS, T.M.; SILVA, E.N.; RAMALHO, F.S. Desenvolvimento ninfal de Podisus connexivus Bergroth (Hemiptera: Pentatomidae) alimentado com curuquerê-do-algodoeiro. Pesquisa Agropecuária Brasileira, v.30, p.163167, 1995.

SCHUSTER, M.F.; LUKEFAHR, M.J.; MAXWELL, F.G. Impact of nectariless cotton on plant bugs and natural enemies. Journal of Economic Entomology, v.69, p.400-402, 1976.

SOARES, J.J.; LARA, F.M.; BUSOLI, A.C.; ALMEIDA, R.P. de; BRAGA SOBRINHO, R. Problemas com inseticidas na cultura algodoeira. Jaboticabal: FUNEP, 1995. 25p.

UNIVERSIDADE ESTADUAL PAULISTA "JÚLIO DE MESQUITA FILHO". Departamento de Ciências Exatas. ESTAT. Versão 2.0. Jaboticabal: FCAV:UNESP, 1994.

ZANUNCIO, J.C.; ALVES, J.B.; ZANUNCIO, T.V.; GARCIA, J.F. Hemipterous predators of eucalypt defoliator catterpillars. Forest Ecological and Management, v.65, p.65-73, 1994.

ZANUNCIO, T.V. Biologia do predador Supputius cincticeps (Hemiptera: Pentatomidae) em larvas de Musca domestica e de Tenebrio molitor. Viçosa, 1992. 59p. Dissertação (M.S.) - Universidade Federal de Viçosa.

ZUMMO, G.R.; BENEDICT, J.H.; SEGERS, J.C. No-choice study of plantinsect interactions for Heliothis zea (Boddie) (Lepidoptera: Noctuidae) on selected cottons. Environmental Entomology, v.12, p.1833-1836, 1983.

Received October 24, 2001 